УдК 316.35

DOI: 10.18101/1994-0866-2020-1-60-65

\title{
ТЕОРЕТИЧЕСКИЕ ПОДХОДЫ В ИЗУЧЕНИИ ТУРИСТСКОЙ ДЕСТИНАЦИИ
}

\author{
(C) Малышева Евгения Олеговна \\ аспирант, \\ Российский государственный педагогический университет им. А. И. Герцена \\ Россия, 667000, г. Кызыл, ул. Красных Партизан, 18 \\ E-mail: evgena.malysheva@gmail.com
}

В статье рассматриваются основные подходы в изучении туристской дестинации как социального явления. Социальная сущность туристской дестинации основывается на потребности человека в перемещении из одной местности в другую с различными целями, мотивами и установкам. Критериями оценки дестинации являются синтез социальных, культурных, физических характеристик, формирующих для туристов уникальную региональную идентичность, а также комплекс туристических услуг, основанных на широком спектре ресурсов, продуктов и др. Изучая основные подходы, критерии и методы, важно формировать управленческие механизмы в функционировании туристской дестинации регионов, находящихся на приграничных территориях. Требуется грамотное управление на основе эффективной внешней, внутренней политики, а также регулирование информационной и туристической среды.

Ключевые слова: туризм; туристская дестинация; местность; территория; география; региональная идентичность; социальное управление дестинацией; кластеры дестинации.

\section{Для цитирования}

Малымева E. O. Теоретические подходы в изучении туристской дестинации // Вестник Бурятского государственного университета. Философия. 2020. Вып. 1. C. 60-65.

С глубокой древности человек путешествовал и покорял новые территории поисках лучших мест проживания. Термин «путешествие» трактуется как ознакомление с новыми территориями. Организованное управление туризмом началось с момента развития торговых отношений, когда люди преодолевали большие пространства, чтобы перевозить товары до назначенных пунктов следования, по пути знакомясь не только с территориями, но и культурой, бытом других народов. Наиболее благоприятные местности открывали для человека возможность получения прибыли. Лидеры завоевывали регионы с целью освоения торговых путей, рынков сбыта, стремясь получить влияние над населением. Покорение народов началось также с распространения духовных учений великих деятелей, которые проповедовали новые философские знания. Одним из выдающихся учителей прошлого являлся Будда Шакьямуни, и его учение распространилось из Древней Индии по всему Ближнему Востоку и Азии. Таких учителей, странников, торговцев встречали на новых террито- 
риях, предоставляя им элементарные услуги проживания и питания. С развитием цивилизации совершенствовалась инфраструктура, в связи с этим и туристические предложения. Во времена развития торговых путей люди обменивались товарами, различными бытовыми принадлежностями, знаниями о мире и технике. В целях совершенствования передвижений по торговым путям развивалась транспортная инфраструктура. Мобильность человека создавала большие возможности для новых открытий в технике, культуре, туризме. Познавательные потребности привели к созданию институтов постоянного образования. Были созданы образовательные центры, которые стали привлекать новое поколение с новым мышлением о вселенной. Крупные образовательные центры находились в античных, средневековых городах, в которых развивались услуги гостиничного, экскурсионного, развлекательного, религиозного и бытового типов.

Толчком к развитию массового туризма явился технический прогресс. Созидателями прогресса были исследователи, которых поддерживала управленческая элита, заинтересованная в распространении своего влияния и извлечении материальной прибыли. Созданные средства передвижения стали катализатором массовых путешествий с целью познавательного интереса, образования, получения выгоды, оздоровления и отдыха и т. д. Туристическая индустрия развивалась, знатоки туризма создавали международные туристические центры, которые стали предлагать туристические услуги в виде пакетных туров. Как только туризм стал массовым, началось возведение туриндустрии - развитие дорог, гостиниц, ресторанов, парков, зон отдыха и лечебных учреждений. Туризм определил четыре основных интереса людей - спортивный, познавательный, эстетический и коммуникабельный [7]. В целом туризм в истории развития общества сыграл колоссальную прогрессивную роль, развивая транспорт, торговлю, дипломатические отношения, способствуя позитивному влиянию на ментальность людей, расширяя социальную мобильность.

Слово «туризм» происходит от латинского слова tornus (движение по кругу; вертеть, вращать). В широком смысле оно означает передвижение с одновременной сменой быта людей [6]. Международная ассоциация научных экспертов в области туризма определяет туризм как совокупность отношений и явлений, возникающих во время перемещения и пребывания людей в местах, отличных от их постоянного места проживания и работы. Гаагская межпарламентская декларация по мировому туризму 1989 г. устанавливает, что перемещения являются свободными, основанными на удовлетворении потребностей.

Понятие «дестинация» (с английского языка destination) означает место назначения, назначение, предназначение, цель путешествия, похода и т. д. В Оксфордском словаре понятий и терминов дестинация трактуется «как место, куда направляется человек или вещь» (на англ. destination - the place to which a person or thing is going). В английском языке дефиниция «дестинация» имеет ярко выраженный территориальный характер.

Данное понятие впервые использовал Томас Кук, организовывая экскурсии за здоровый образ жизни, разработал программу с описанием города Лафборо, где и 
планировался съезд Ассоциации трезвенников южных графств центральной Англии [3].

В конце XX в. термин «дестинация» стал официальным в сфере туризма и в буквальном смысле понимается как место назначения, регион, географическая территория, социально-географическая местность, которую турист посещает, выбирает с определенной целью (отдых, рекреация, деловые, экскурсионные поездки и т. д.). Самым важным критерием в данной дефиниции является территория, куда направляется турист в определенный промежуток времени.

Автор одного из самых известных словарей по туризму С. В. Медлик отмечает, что туристская дестинация имеет территориальный аспект, куда входят такие понятия, как страны, регионы, города или другие территории, которые посещают туристы. Важность конкретной географической территории как туристской дестинации определяется тремя факторами: доступностью, аттракциями и инфраструктурой [1]. На основе анализа данных определений можно отметить, что туристическая территория - это не только физические, материальные достижения и особенности, но и аттракции, а именно привлекательность территории, создающая основу для передвижения людей. Туристические аттракции - это отношения между туристом, достопримечательностью и рынком. Если есть интерес, значимость, привлекательность, отдача от места для туриста, то возникают аттракции.

Российские исследователи также дополняли отличительные признаки и характеристики в определении туристской дестинации. С позиции географического подхода рассматриваемый объект исследования тесно переплетается с идентичными концептами, такими как «туристический регион», «центр туризма», «туристический центр», «туристический район», которые в большей степени составляют пространственный ареал туристской дестинации. С учетом пространственной иерархии в Российской Федерации наиболее «востребованной» единицей является регион, определяющийся как большой район, часть территории с физико-географическими параметрами, социально-экономической системой и ограниченными географическими рубежами. Управление регионами представляет федеративную концепцию с централизованной структурой распределения власти. Федеральное управление концентрируется в эпицентре европейской части страны, тогда как другие части примыкают к центру, создавая целостную, единую картину мира. Структура управления распадается на эпицентр, регион, район, город, микрорайон, квартал и другие.

Субъект туристской дестинации (государство, регион, район, сельская местность, туристическая организация) предлагает и продает объекту (туристу) туристический продукт, который привлекает отдыхающих своей уникальностью, неповторимостью, новизной (природа, культура, быт народа и т. д.). Субъект включает туристические ресурсы и инфраструктуру (предприятие, транспорт, размещение, питание, экскурсионное обслуживание, персонал, местное население), основной деятельностью которого является обслуживание туриста на всем промежутке посещения туристской дестинации.

Туристская дестинация - это социальное пространство, которое обладает аттрактивными предложениями в ответ на спрос туристов, желающих получить мак- 
симум визуальных насыщений. Социальное пространство имеет физические и административные границы, обусловливающие способ его управления, образы и перцепции, определяющие его рыночную конкурентоспособность. Турист выражает запрос на территорию, которая должна обладать определенными характеристиками и свойствами, быть аттрактивной.

Следующий социопсихологический подход направлен на объяснение дестинации с позиции ее привлекательности, которая формируется не только внешними атрибутами (география, этнография, быт), но и социально-культурными и сервисными ценностями, которые изменяются под воздействием социально-экономической ситуации и общественного строя [5]. Привлекательность территории, как отмечал М. А. Морозов, зависит в том числе от наличия определенного набора услуг, необходимых для принятия туристов, причем это должен быть тот набор и того качества, которые туристы ожидают, приобретая предлагаемый ему туристический продукт [4].

Управленческие процессы определяют первенство удовлетворения тех или иных потребностей человека, и со временем происходит усложнение удовлетворения потребностей. Сегодня современный турист в отличие от завоевателей, купцов привозит из других стран не материальный капитал, а совокупность знаний, впечатлений, т. е. культурный капитал [2].

Современный туризм становится мощным агентом социальных и культурных преобразований. Происходит социальное развитие народов, которое ведет к культурному, духовному, политическому, идейному обогащению. Туризм воздействует на общественные процессы и развитие соответствующих социальных заказов, поэтому является культурным, духовным, психологическим, экзистенциальным измерением. Туристическая деятельность строится на матрице всего пространства, в котором переплетены социальные отношения. Совокупность взаимодействий субъекта и объекта туристической деятельности образует два поля целедостижений - духовное, психическое, экзистенциальное обогащение и физическое потребление.

Социальная сущность туризма основывается на туристической деятельности, включающей в себя интеракцию объектов и субъектов туризма, обладающих различными потребностями и мотивами [8]. Деятельность реализуется целенаправленными действиями, обеспечивающими экономическую выгоду, увеличение туристических потоков для управляющей системы, поддержание здоровья, рекреацию, отдых, досуг и другое для управляемых туристических потоков. Эти субъектобъектные отношения основаны на территориальной привязке.

Дестинация - это географическая территория, привлекательная для туристов, совокупность инфраструктуры и услуг, особенности природных, этноместкультурной специфики, которые подобраны таким образом, чтобы соответствовать потребностям и ожиданиям туристов. Критериями оценки дестинации является синтез социальных, культурных, физических характеристик, которые формируют уникальную, узнаваемую, различимую туристами региональную идентичность, а также комплекс туристических услуг, основанных на широком спектре ресурсов, продуктов и т. д. Кроме того, наличие разнообразной инфраструктуры обеспечивает потребность в питании, проживании, безопасности и развлечениях. На данной терри- 
тории должна существовать система, позволяющая туристу воспользоваться необходимыми услугами - информационными, развлекательными, туроператорскими и др. Регион должен иметь транспортную доступность, соответствующие управленческие структуры, отвечающие за туризм и гостеприимство, что, в свою очередь, интегрируется с социально-экономическим развитием.

Социальное управление дестинацией предполагает соединение часто разрозненных элементов для предоставления туристу единого конкурентоспособного продукта. Субъектами управления являются специализированные государственные, общественные, частно-государственные институты и организации, предприятия сферы сервиса и гостеприимства, отвечающие за развитие туристической местности, повышение ее конкурентоспособности.

Дестинация воспринимается туристом и формируется именно под его потребности, конечно, границы дестинации и административные границы не всегда совпадают. Социальное управление дестинацией основано на совокупности менеджмента кластеров достопримечательностей, удобства, доступности, информированности, регулирования руководящими органами.

Кластер достопримечательностей выполняет организационную деятельность по защите и сохранению природных памятников, природных богатств. Кластер удобства объединяет менеджмент объектов размещения, питания, развлечения, розничной торговли, предприятий сфер банковских, медицинских, косметологических услуг. Кластер информированности предоставляет рекламные услуги, управление информационными каналами, разработку положительного бренда дестинации. Кластер доступности обеспечивает транспортную активность, поддерживает авиасообщения и автодорожную связь с туристическими рынками. Кластер регулирования руководящими органами создает непосредственную связь с управленческим органом туризма с государственными службами по безопасности (полиция, МЧС, службы по экологической, торговой, сырьевой безопасности).

Социальное управление туристской дестинацией основывается на эффективной внешней, внутренней политике и на грамотном управлении информационными потоками в области туризма, правильном управлении всей туристической средой. Управленческий механизм в туристской дестинации должен затрагивать развитие конгрессно-выставочной деятельности, продвижение туристско-рекреационных возможностей, усиление туристической инфраструктуры. В социальном управлении главным является достижение обеспечения содружества с соседними регионами на основе регионально-частного партнерства, а также создание стратегических альянсов для совершенствования и повышения уровня обслуживания на предприятиях общепита, коллективных средств размещения, транспорта, развлекательных, культурных и образовательных организаций.

Туристская дестинация имеет многогранный спектр социального управления, начиная с расчетов, мотивов в планировании и действии на базе программ, проектов в целях достижения положительного сальдо, имиджа и бренда. Туристская дестинация обладает большим социальным эффектом, в котором взаимодействует множе- 
ство секторов, кластеров, групп, акторов туризма, представляя собой социокультурный институт.

Литература

1. Medlic S. Dictionary of travel tourism and hospitality. 2 ed. Oxford: ButterworthHeinwmann, 1993. P. 273.

2. Добреньков В. И., Кравченко А. И. Фундаментальная социология. Культура и религия. M., 2007. C. 174.

3. Зорин И. В. Туристские дестинации. М., 2011. С. 19.

4. Морозов М. А. Туристские дестинации и закономерности их развития: монография. M., 2005. C. 54.

5. Павлова Э. Н. Дестинация как концепт развития региональной системы непрерывного профессионального туристического образования: автореф. дис. ... д-ра пед. наук. М., 2010. C. 4.

6. Петровский В. С. Туризм как общественное явление // Спутник туриста. Киев, 1983. C. 7. C. 155 .

7. Пузакова Е. П., Честникова В. А. Международный туристический бизнес. М., 1997.

\section{THEORETICAL APPROACHES TO THE STUDY OF TOURIST DESTINATION}

Evgeniya O. Malysheva

Research Assistant,

Herzen State Pedagogical University of Russia

18 Krasnykh Partizan St., Kyzyl 667000, Russia

E-mail: evgena.malysheva@gmail.com

The article considers the main approaches to the study of tourist destination as a social phenomenon. The social essence of tourist destination lies in the needs of a person to move from one locality to another with different goals, motives and attitudes. The criteria of destination assessment involve synthesis of social, cultural and physical characteristics that form a unique regional identity for tourists. An equally important component of tourist destination is a complex of tourist services based on a wide range of resources: a diverse infrastructure, providing for the needs in food, accommodation, security and entertainment. While studying the main approaches, criteria and methods, it is important to create effective managerial mechanisms for the functioning of tourist destination in the border regions. They should be based on the effective foreign and domestic policy, regulation of the information and tourism environment.

Keywords: tourism; tourist destination; locality; territory; geography; regional identity; social management of destination; clusters of destination. 